\title{
Regulation of Binding Proteins for Insulin-like Growth Factors (IGF) in Humans Increased Expression of IGF Binding Protein 2 during IGF I Treatment of Healthy Adults and in Patients with Extrapancreatic Tumor Hypoglycemia
}

J. Zapf, Ch. Schmid, H. P. Guler, M. Waldvogel, Ch. Hauri, E. Futo, P. Hossenlopp, * M. Binoux," and E. R. Froesch Metabolic Unit, Department of Medicine, University Hospital of Zürich, CH-8091 Zürich, Switzerland; and *Institut National de la Santé et de la Recherche Médicale Unité 142, Hôpital Trousseau, F-75012 Paris, France

\begin{abstract}
Insulin-like growth factors (IGFs) in blood form two complexes with specific binding proteins (BPs): a large, growth hormone (GH)-dependent complex with restricted capillary permeability, and a smaller complex, inversely related to $\mathbf{G H}$, with high turnover of its IGF pool and free capillary permeability. The distribution of BPs and of IGFs I and II between these complexes was studied in sera from healthy adults treated with IGF I or/and GH and from patients with extrapancreatic tumor hypoglycemia. Like GH, IGF I administration raises IGF I and two glycosylation variants of IGFBP-3 in the large complex, but unlike GH drastically reduces IGF II. During IGF I infusion, IGFBP-3 appears in the small complex whose IGFBP-2 and IGF I increase three- to fivefold and fivefold, respectively. GH treatment, associated with elevated insulin levels, suppresses IGFBP-2 and inhibits its increase owing to infused IGF I. The small complex of tumor sera contains increased amounts of IGFBP-2 and -3 , and two- to threefold elevated IGF II. Conclusions: low GH and/or insulin during IGF I infusion and in extrapancreatic tumor hypoglycemia enhance expression of IGFBP-2 and favor partition of IGFBP-3 into the small complex. Free capillary passage and high turnover of its increased IGF I or II pools may contribute to compensate for suppressed insulin secretion during IGF I infusion or to development of tumor hypoglycemia. (J. Clin. Invest. 1990. 86:952-961.) Key words: IGF binding proteins • IGF I treatment • extrapancreatic tumor hypoglycemia
\end{abstract}

\section{Introduction}

Insulin-like growth factors (IGFs) ${ }^{1}$ are synthesized and released by many tissues and cell types $(1,2)$. The liver contributes most of the IGFs in the circulation $(1,3)$. IGFs are always found in association with specific high-affinity binding proteins (2). As is true for IGFs, the highest concentrations of IGF

Part of this work was presented in preliminary form at the 71 st Annual Meeting of the Endocrine Society, Seattle, WA, 21-24 June 1989 (abstract no. 1007).

Address reprint requests to Dr. Zapf, Metabolic Unit, Department of Medicine, University Hospital, CH-8091 Zurich, Switzerland.

Received for publication 15 December 1989 and in revised form 12 March 1990.

1. Abbreviations used in this paper: GH, growth hormone; IGF, insulin-like growth factor; IGFBP, IGF binding protein; rh, recombinant human.

J. Clin. Invest.

(c) The American Society for Clinical Investigation, Inc.

$0021-9738 / 90 / 09 / 0952 / 10 \quad \$ 2.00$

Volume 86, September 1990, 952-961 binding proteins (IGFBPs) are found in blood. However, they have also been detected in interstitial and cerebrospinal fluid $(2,4,5)$ and in media of cultured cells or organ explants $(2,6-8)$.

The physiological role of the IGFBPs is not yet completely unraveled. They prolong the half-life of the IGFs in the circulation $(9,10)$ and protect the organism against acute insulinlike effects of the IGFs $(10,11)$. In the interstitial fluid they may modulate the bioavailability of locally secreted IGFs to IGF target cells $(7,8,12-14)$. Finally, they appear to be involved in specific IGF targeting $(11,15)$.

Native adult human serum contains two IGFBP complexes with respective apparent molecular masses of $160-180^{2}$ and $50-55 \mathrm{kD}(16)$. The large complex is growth hormone (GH)dependent $(17,18)$. It consists of glycosylated IGF binding subunits, IGF itself, and a glycosylated acid-labile protein which binds only IGF complexed with IGF binding subunits $(19,20)$. The small complex is inversely related to the GH status (17). The chemical nature of its constituents has not yet been completely elucidated.

Infusion of recombinant human (rh)IGF I into normal adults inhibits insulin and GH secretion, suppresses serum IGF II levels, and increases renal function (21). In this context, we looked for possible changes of IGFBPs and discovered that rhIGF I "induces" a specific IGFBP, which is the predominant form in human fetal sera and in sera of patients with Laron dwarfism and with extrapancreatic tumor hypoglycemia.

\section{Methods}

\section{Subjects and experimental protocol}

Serum samples were from the same two subjects as in the study of Guler et al. (21). The experimental protocol and the infusion regime have been described in detail. rhIGF I (a generous gift from Dr. W. J. Rutter, Chiron Corp., Emeryville, CA and Dr. J. Nüesch, Ciba-Geigy AG, Basel) was infused s.c. at a rate of $20 \mu \mathrm{g} / \mathrm{kg}$ body weight per $\mathrm{h}$ for 6 d. RhGH (Norditropin, Nordisk Gentofte, Denmark) was injected at a dose of $2 \times 3 \mathrm{mg} / \mathrm{d}$ s.c. for $6 \mathrm{~d}$. On days 5 and 6 , rhIGF I was infused together with GH treatment. Fetal sera were obtained from infants delivered between 27 and 43 wk of gestation. Sera from patients with extrapancreatic tumor hypoglycemia were obtained from referring physicians from several European countries. All sera were stored at $-20^{\circ} \mathrm{C}$ until used for analysis.

\section{Sephadex gel permeation chromatography}

Radiochromatographic patterns of sera. $0.2 \mathrm{ml}$ serum diluted with 0.3

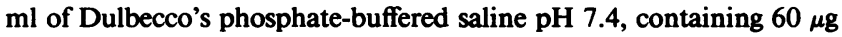
of $\mathrm{NaN}_{3}$ and $500 \mathrm{U}$ of Trasylol (Bayer, Leverkusen, FRG), was incu-

2. In our hands this complex elutes reproducibly at an apparent molecular mass of $160-180 \mathrm{kD}$ on Sephadex G-200 gel permeation chromatography of human serum at neutral $\mathrm{pH}$. 
bated for $24 \mathrm{~h}$ at $4^{\circ} \mathrm{C}$ with ${ }^{125}$ I-labeled IGF I or II (4-6 $\times 10^{5} \mathrm{cpm}, 2-3$ $\mathrm{ng})$ and passed over a Sephadex G-200 column $(2 \times 70 \mathrm{~cm}$, pumping rate $13 \mathrm{ml} / \mathrm{h}$ ), calibrated with a gel filtration calibration kit (Pharmacia, Uppsala, Sweden). The radioactivity of the fractions was measured in a $\gamma$-counter (Berthold, Wildbad, FRG). Nonspecific binding was assessed in the presence of excess unlabeled IGF (11). Radiochromatographic patterns of human sera are identical with ${ }^{125}$ I-IGF I or ${ }^{125}$ IIGF II (J. Zapf, unpublished observation).

Fractionation of sera on Sephadex G-200. 1-ml serum samples were passed over the same column as used for radiochromatography and eluted under identical conditions. The $\gamma$-globulin and albumin peaks were used for internal calibration during successive runs. Fractions corresponding to an apparent molecular mass range of 120-300 kD (pool I), 50-120 kD (pool II), and 21-50 kD (pool III) were pooled, dialyzed against $0.1 \mathrm{M} \mathrm{NH}_{4} \mathrm{HCO}_{3}$, lyophilized, and dissolved in $1 \mathrm{ml}$ (pools I and II) or $0.5 \mathrm{ml}$ (pool III) of distilled water for ligand blot analysis (see below) and for determination of IGF I and II by radioimmunoassay (RIA) (22). Before the RIA, carrier proteins were removed by Sep-Pak chromatography according to the instructions of the supplier (Waters Associates, Milford, MA).

Fractionation of sera on concanavalin A (Con A) Sepharose. $0.1 \mathrm{ml}$ of serum diluted with $0.1 \mathrm{ml} 0.05 \mathrm{M}$ sodium phosphate buffer, $\mathrm{pH} 7.4$, containing $0.2 \mathrm{M} \mathrm{NaCl}$ and $0.02 \% \mathrm{NaN}_{3}$ (starting buffer) was passed over $2 \mathrm{ml}$ Con A Sepharose columns as described (11). The adsorbed and nonadsorbed fractions were dialyzed against $0.1 \mathrm{M} \mathrm{NH}_{4} \mathrm{HCO}_{3}$, lyophilized, and taken up in $100 \mu \mathrm{l}$ of distilled water for ligand blot analysis.

Analysis of IGFBPs by ligand blotting. The method of Hossenlopp et al. (23) was used with slight modifications (11). 3-5 $\mu \mathrm{l}$ of serum or $5-10 \mu \mathrm{l}$ of pooled serum fractions were electrophoresed for $5 \mathrm{~h}$ at 170 $\mathrm{mV}$ on SDS/15\% polyacrylamide slab gels under nonreducing conditions (except the ${ }^{14} \mathrm{C}$-labeled molecular weight markers; Rainbow
Marker, Amersham International, Amersham, UK). Electroblotting on nitrocellulose was performed in a transblot cell (Bio-Rad Laboratories, Richmond, CA) for $2 \mathrm{~h}$ at 0.6-1.0 A. The air-dried nitrocellulose sheets were processed as described $(11,23)$ except that $1 \%$ fish gelatine (LB solution, Inotech, Wohlen, Switzerland) was used instead of albumin to block nonspecific binding sites. Each sheet was incubated for 6 $\mathrm{h}$ at room temperature in a sealed plastic bag with $4 \times 10^{6} \mathrm{cpm}$ of ${ }^{125}$ I-labeled IGF I or II (11), washed extensively $(11,23)$, air-dried, and exposed for $8-48 \mathrm{~h}$ at $-70^{\circ} \mathrm{C}$ to X-ray film (X-Omat AR) in a Kodak $\mathrm{X}$-Omatic cassette (Eastman Kodak Co., Rochester, NY).

For quantitative analysis, the nitrocellulose membrane was fitted on the autoradiogram on a fluorescent screen, and the bands were marked with a pencil on the nitrocellulose membrane. Marked bands were cut out and counted in a $\gamma$-counter. Corresponding strips of each lane showing "background activity" were also counted and the counts were subtracted.

Digestion of samples with $N$-glycanase. Samples (20-30 $\mu \mathrm{g}$ of protein) were incubated for $30 \mathrm{~min}$ at room temperature in $19 \mu \mathrm{l}$ of $0.2 \mathrm{M}$ sodium-phosphate buffer, $\mathrm{pH} 8.6$, containing $16 \%$ glycerol and 0.79 mM EDTA with or without $1.5 \mathrm{U}$ of $N$-glycanase (Genzyme Corp., Boston, MA). Samples were electrophoresed and blotted as described above.

\section{Results}

${ }^{125}$ IGF-ligand blot patterns of normal and pathological human sera. A typical ligand blot pattern of normal adult human serum contains three major bands: a strong and broad double band (doublet) at $42 / 45 \mathrm{kD}$ and a narrow, faint band at $36 \mathrm{kD}$ (Fig. 1). Sometimes a band appears at $24 \mathrm{kD}$ (Figs. $2 a$ and $3 a$ ). After longer exposure times, a faint, broad band is recognized

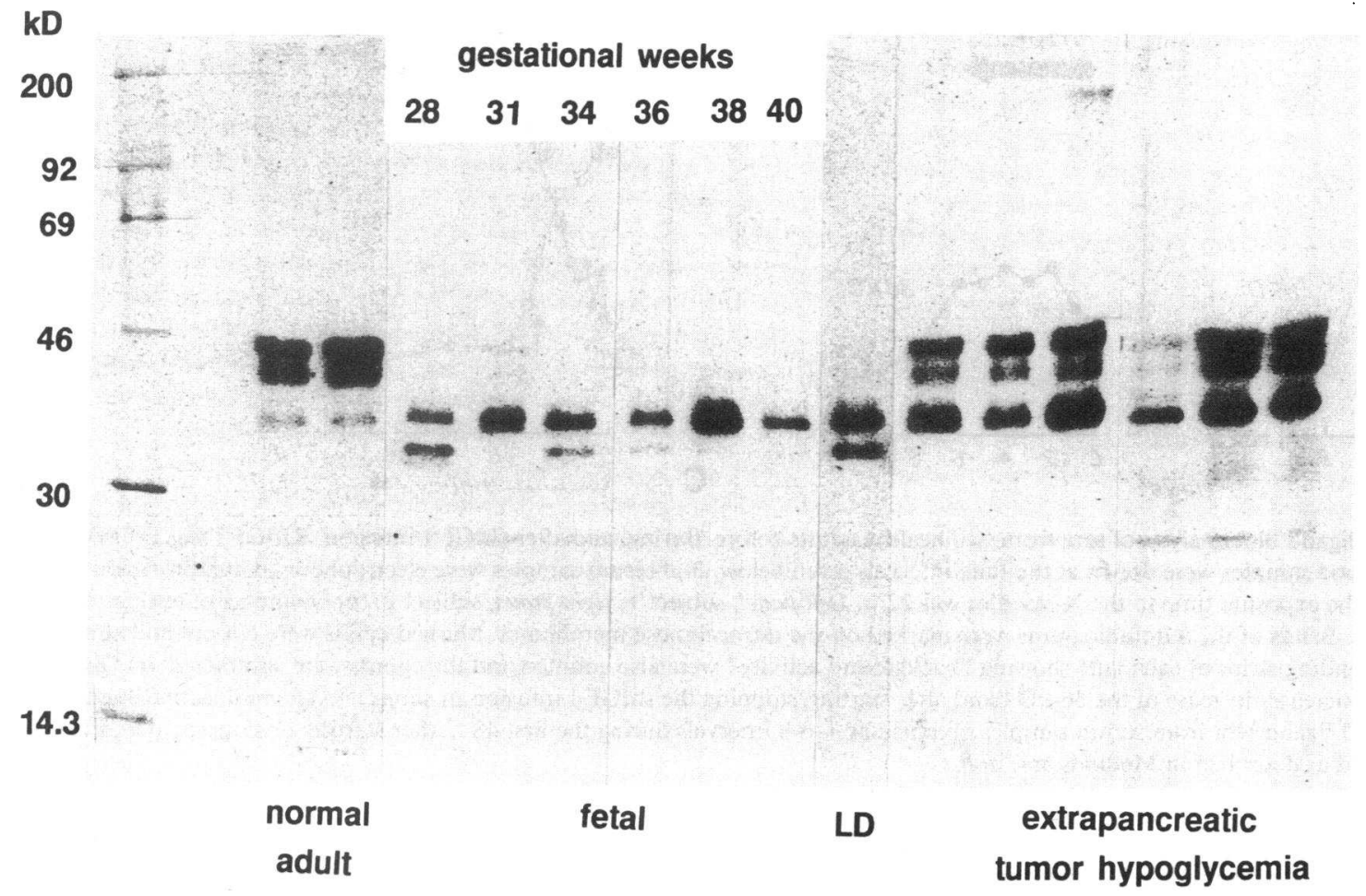

Figure 1. ${ }^{125}$ I-IGF II ligand blot analysis of various human sera. 3- $\mu$ l serum samples were electrophoresed on $15 \%$ SDS-polyacralymide gels and processed as described in Methods. The nitrocellulose membranes were exposed to the X-ray film for $20 \mathrm{~h}$. The first two lanes represent sera from two different pools of normal adults. LD, Laron dwarf. Sera from patients with extrapancreatic tumor hypoglycemia (from left to right): three fibrosarcomas, a carcinoma of the colon, a lung tumor (unknown histology), a mesothelioma of the pleura. Total serum IGF I and II levels in these patients were as follows: IGF I-94, 64, 37, 18, 101, $124 \mathrm{ng} / \mathrm{ml}$; IGF II $-452,200,482,309,352,510 \mathrm{ng} / \mathrm{ml}$. 

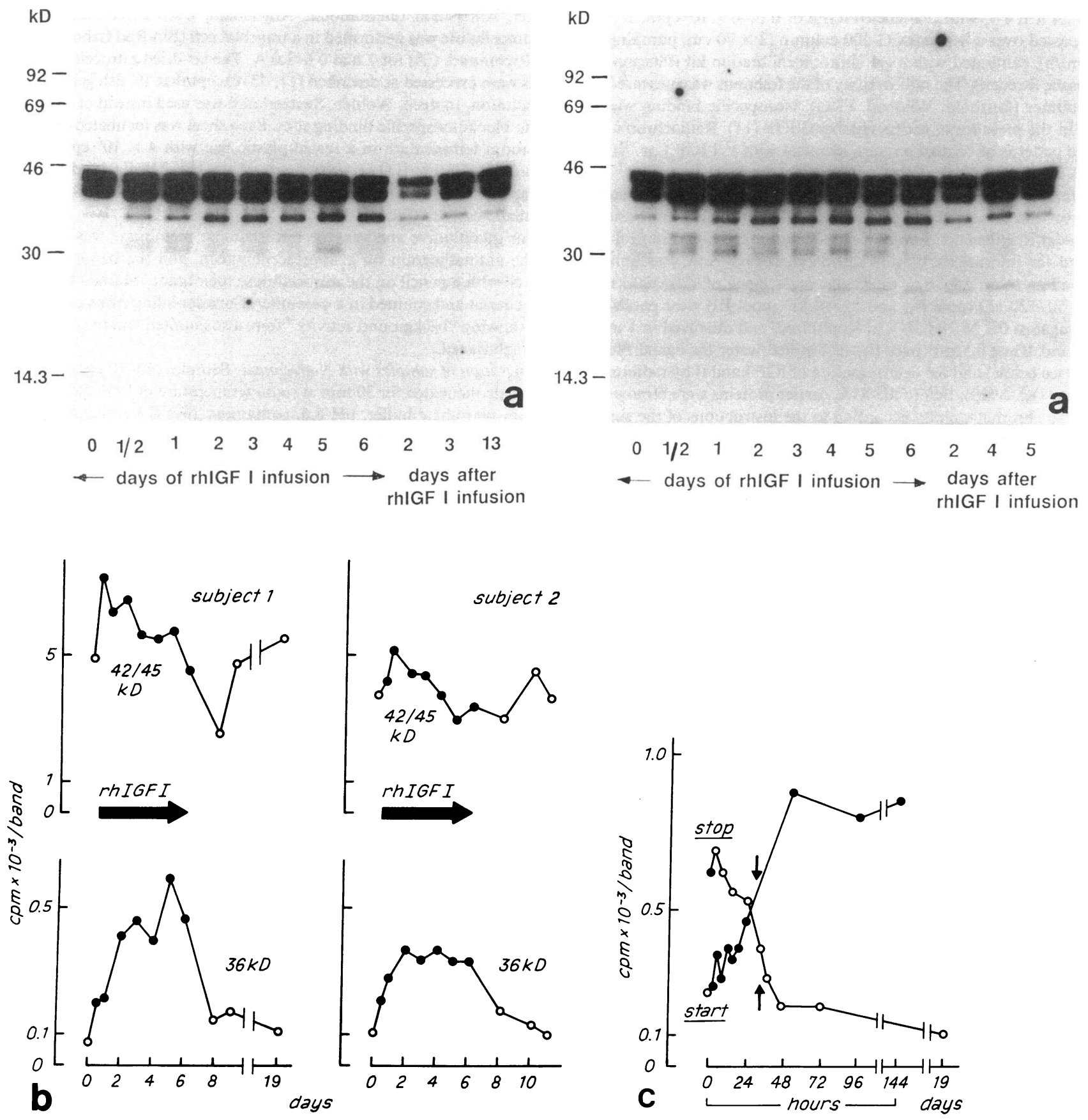

Figure 2. (a) ${ }^{125}$ I-IGF II ligand blot analysis of sera from two healthy adults before, during, and after rhIGF I infusion. RhIGF I was infused at a dose of $30 \mathrm{mg} / \mathrm{d}$, and blood samples were drawn at the time intervals given below. 3- $\mu$ l serum samples were electrophoresed and processed as described in Methods. The exposure time to the X-ray film was $22 \mathrm{~h}$. Left panel, subject 1; right panel, subject 2. (b) Quantitative evaluation of the ligand blots of Fig. 2. Bands of the autoradiograms were marked on the nitrocellulose membranes. Marked bands were cut out and counted in a $\gamma$-counter. Corresponding strips of each lane showing "background activity" were also counted and the counts were subtracted. (c) Quantitative evaluation of the increase/decrease of the 36-kD band after starting/stopping the rhIGF I infusion in subject 1 . The radioactive bands of a corresponding ${ }^{125} \mathrm{I}$-IGF II ligand blot from serum samples obtained at 3-6-h intervals during the first $48 \mathrm{~h}$ after starting or stopping the infusion were cut out and counted as described in Methods and in $b$.

between 28 and $30 \mathrm{kD}$ (not shown). This pattern is identical with ${ }^{125}$ I-labeled IGFs I or II, but the signals are more intense with ${ }^{125}$ I-IGF II after identical exposure times. The bands disappear when the nitrocellulose is incubated in the presence of excess unlabeled IGF (not shown).

The most prominent bands in fetal serum are the 36 - and a
33-kD band which is not seen in normal adult serum. The $42 / 45-\mathrm{kD}$ doublet is missing or of low intensity (Fig. 1).

A pattern similar to that of fetal serum was found in a patient with Laron dwarfism (Fig. 1). In extrapancreatic tumor hypoglycemia, the $36-\mathrm{kD}$ signal is enhanced. The intensity of the $42 / 45-\mathrm{kD}$ doublet can be reduced or normal (Fig. 1). The 

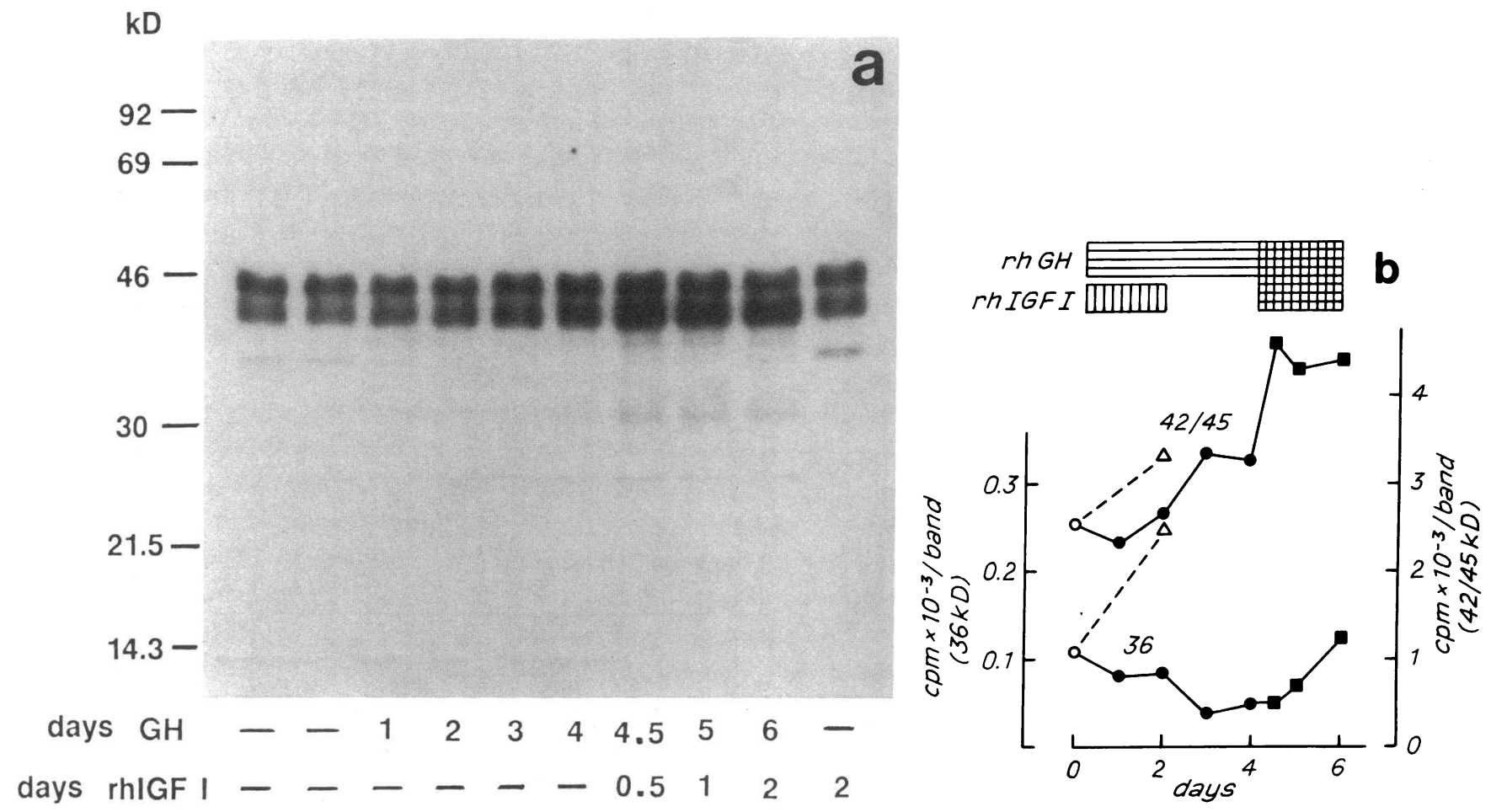

Figure 3. (a) ${ }^{125}$ I-IGF II ligand blot analysis of sera from a healthy adult (subject 1$)$ before and during treatment with growth hormone $(2 \times 3$ $\mathrm{mg} \mathrm{d} / \mathrm{s} . c$.), growth hormone (same dose) + rhIGF I (infusion of $30 \mathrm{mg} / \mathrm{d}$ ) or rhIGF I alone $(30 \mathrm{mg} / \mathrm{d}$ ). Blood was drawn after different times of treatment, as given below the figure. 3- $\mu \mathrm{l}$ serum samples were electrophoresed and processed as described in Methods. Exposure time was $22 \mathrm{~h}$. (b) Quantitative evaluation of the ligand blot of $a$. Radioactive bands were marked, cut out, and counted as described in Methods and in Fig. 2

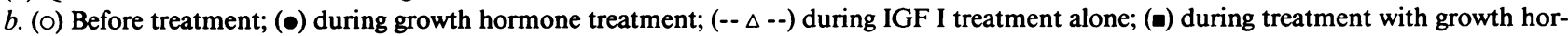
mone and IGF I.

ratio between the intensities of the $36-\mathrm{kD}$ band and the $42 / 45$ $\mathrm{kD}$ doublet is always greater than in normal adult serum.

Changes of the ${ }^{125}$ I-IGF ligand blot pattern during IGF I and $h G H$ administration in healthy adults. Infusion of rhIGF I s.c. results in typical changes of the ${ }^{125}$ I-IGF ligand blot pattern (Fig. $2 a$ ): (a) the intensity of the $36-\mathrm{kD}$ band increases in both subjects (Fig. 2, $a$ and $b$ ) with a half-life of $30 \mathrm{~h}$ (Fig. 2, $b$ and $c$ ); (b) the 42/45-kD signal shows a transient increase (Fig. $2 b$ ); (c) two other bands appear at 31 and $33 \mathrm{kD}$ (Fig. $2 a$ ). All of these changes are reversible. The $36-\mathrm{kD}$ signal decreases with a halflife of $30 \mathrm{~h}$ (Fig. 2, $b$ and $c$ ).

The intensity of the $42 / 45-\mathrm{kD}$ doublet increases $2 \mathrm{~d}$ after GH administration (Fig. 3). IGF I further enhances this increase (Fig. 3, $a$ and $b$ ). However, in contrast to IGF I, GH reduces the $36-\mathrm{kD}$ signal. This is particularly obvious when GH and rhIGF I are administered together (Fig. $3 a$, last two lanes, and Fig. $3 b$ ).

Characterization of the ${ }^{125}$ I-IGF ligand blot bands. To characterize the ${ }^{125}$ I-IGF ligand blot bands, we tried to answer the following questions: $(a)$ To which of the two IGFBP complexes of native serum can the above ligand blot bands be assigned? $(b)$ Which of the ligand blot bands represent glycosylated and which nonglycosylated proteins? (c) How are IGFs I and II distributed between the two binding protein complexes before and during IGF I or GH administration and in patients with extrapancreatic tumor hypoglycemia? $(d)$ What is the chemical nature of the proteins represented by the ${ }^{125}$ I-IGF ligand blot bands?
When normal adult human serum preequilibrated with ${ }^{125}$ I-IGF I or II is gel-filtered over Sephadex G-200 at neutral $\mathrm{pH}$, two specific IGFBP complexes elute as radioactive peaks at apparent molecular masses of $160-180$ and $50-55 \mathrm{kD}$ (reference 16 and Fig. 4). During IGF I infusion the large molecular mass peak decreases, whereas the $50-55-\mathrm{kD}$ peak increases and shifts to $60-65 \mathrm{kD}$. In contrast, $\mathrm{GH}$ administration causes an increase of the 160-180-kD peak and a concomitant decrease and shift of the 50-55-kD peak (Fig. 4). Serum fractions were pooled as shown in Fig. 4 (pools I, II, and III) and the concentrated pools were subjected to ligand blot analysis (Fig. 5). Pool I, which contains the native large molecular mass IGFBP complex, yields the $42 / 45-\mathrm{kD}$ doublet and the $31-\mathrm{kD}$ band. The latter is visible only after prolonged exposure times (not shown). The intensity of the doublet in pool I, in particular the intensity of the $42-\mathrm{kD}$ band, is increased during IGF I or GH administration, and further enhanced by the combination of the two hormones (Figs. 2, $a$ and $b$, and 3,a and $b$ ). The increase of the doublet signal in pool I during IGF I infusion contrasts with the decrease of ${ }^{125} \mathrm{I}-\mathrm{IGF}$ I binding to the native 160-180-kD peak (Fig. 4). Apparently, the availability of IGF binding sites is reduced due to increased occupancy by exogenous IGF I (see Table I), which may not be readily exchangeable.

The 36-kD band elutes in pool II within an apparent molecular mass range of 50-120 kD (Figs. 4 and 5). During IGF I infusion, but not during $\mathrm{GH}$ treatment, the $42 / 45-\mathrm{kD}$ doublet appears also in pool II (Fig. 5). The 33-kD band "induced" 


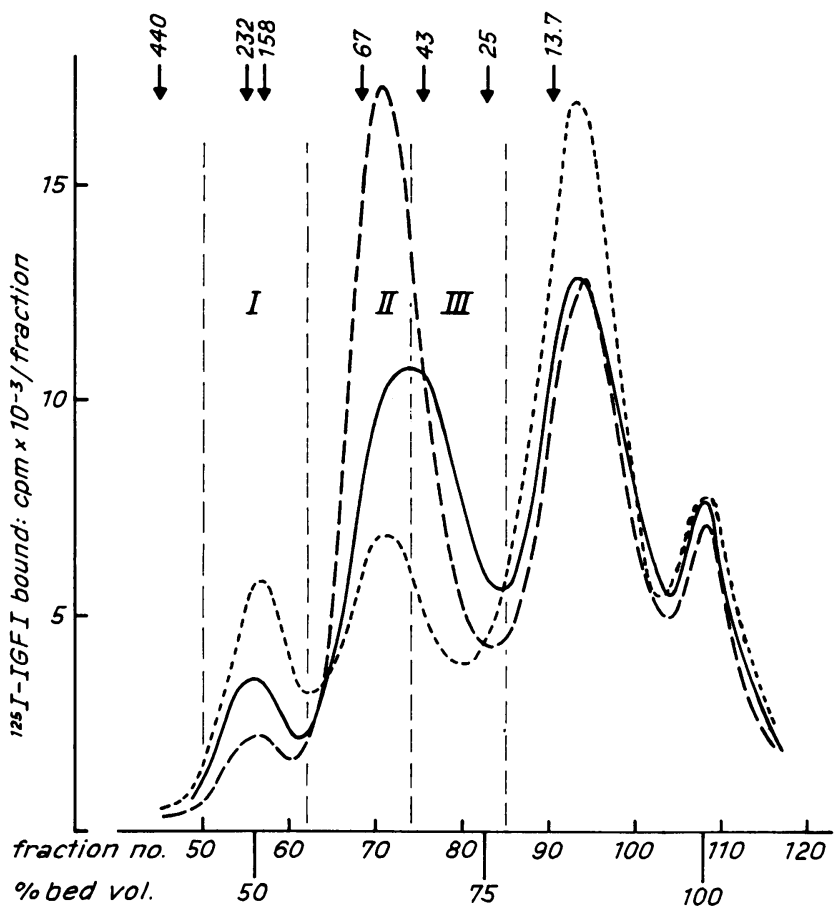

Figure 4. ${ }^{125}$ I-IGF I radiochromatographic patterns of sera from a normal adult (subject 1) treated with hGH $(2 \times 3 \mathrm{mg} / \mathrm{d}$ s.c. for $4 \mathrm{~d}$; dotted line) or rhIGF I ( $30 \mathrm{mg} / \mathrm{d}$ infused s.c. for $2 \mathrm{~d}$; dashed line) compared with a pretreatment serum (solid line). $0.2-\mathrm{ml}$ serum samples were preequilibrated at $4^{\circ} \mathrm{C}$ for $20 \mathrm{~h}$ with ${ }^{125} \mathrm{I}$-IGF I tracer $(580,000 \mathrm{cpm}, 2 \mathrm{ng})$ in a total volume of $0.5 \mathrm{ml}$ adjusted with Dulbecco's buffer and gel-filtered on a Sephadex G-200 column as described in Methods. 2.3- $\mathrm{ml}$ fractions were collected and counted in a $\gamma$-counter. The numbers at the top of the figure give the molecular masses of markers in kilodaltons. Vertical dashed lines and numbers I, II, and III indicate the molecular mass range of fractions that were pooled for the experiment shown in Fig. 5.

during IGF I infusion is detected mainly in pool III together with the 28-30 and the 24-kD band, when more concentrated aliquots are electrophoresed and exposure times are increased (not shown). The increase of the ampli1 de of the radioactive $60-65-\mathrm{kD}$ peak during IGF I infusion (Fig. 4) is reflected by the increased intensity of the $36-\mathrm{kD}$ band and the appearance of the $42 / 45-\mathrm{kD}$ doublet in this molecular mass range. Similarly, the decrease of this peak during $\mathrm{GH}$ administration is reflected by the decrease of the 36-kD band (Fig. $3 \mathrm{~b}$ ).

The above results show that the $42 / 45-\mathrm{kD}$ IGF binding subunits are mainly constituents of the $160-180-\mathrm{kD}$ native carrier protein complex, whereas the $36-\mathrm{kD}$ band represents the predominant constituent of the smaller complex.

Fractionation of sera on Con A-Sepharose confirms that the $42 / 45-\mathrm{kD}$ doublet and the $36-\mathrm{kD}$ band are different entities (Fig. $6 a$ ): the $36-\mathrm{kD}$ protein appears in the flowthrough, whereas the $42 / 45-\mathrm{kD}$ doublet is adsorbed and eluted with $0.25 \mathrm{M}$ methylmannose. Digestion of the $42 / 45-\mathrm{kD}$ doublet with $N$-glycanase yields a single band at $37 \mathrm{kD}$. The nonadsorbed 36- and 33-kD bands are not digestable with $N$-glycanase (Fig. $6 b$ ). In agreement with the results of Figs. 2 and 3, the intensity of the $36-\mathrm{kD}$ band in the flow-through is significantly increased during IGF I infusion, whereas it is diminished during GH treatment (Fig. $6 a$ ).

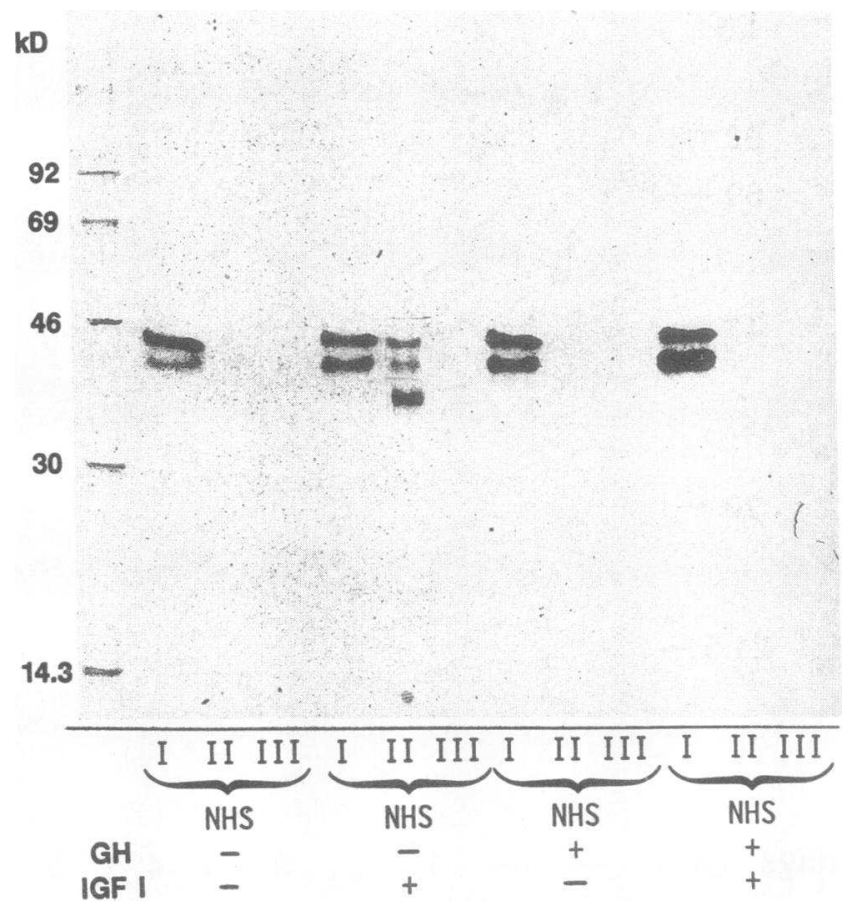

Figure 5. ${ }^{125}$ I-IGF II ligand blot analysis of pooled fractions obtained by neutral Sephadex gel permeation chromatography of sera from a healthy adult (subject 1 ) before and during treatment with rhIGF I or/and rhGH. Serum was obtained before treatment, after $2 \mathrm{~d}$ of rhIGF I infusion $(30 \mathrm{mg} / \mathrm{d}$ s.c. $)$, after $4 \mathrm{~d}$ of rhGH treatment $(2 \times 3$ $\mathrm{mg} / \mathrm{d} \mathrm{s.c.)}$ and after treatment with rhGH + rhIGF I (after $4 \mathrm{~d}$ of $\mathrm{GH}$ treatment rhIGF I was given together with GH for $2 \mathrm{~d}$ more). $1-\mathrm{ml}$ serum samples were gel-filtered on the same Sephadex G-200 column as used for the experiments in Fig. 4 and the fractions were pooled according to the molecular mass ranges indicated by I, II, and III in Fig. 4. The pools were extensively dialyzed against $0.1 \mathrm{M}$ $\mathrm{NH}_{4} \mathrm{HCO}_{3}$, lyophilized, and redissolved in $1 \mathrm{ml}$ (pools I and II) or $0.5 \mathrm{ml}$ (pool III) of distilled water for ligand blot analysis and for IGF I and II determination by RIA (22). 5, 7, and $25 \mu$ l of each pool were electrophoresed and processed as described in Methods. Exposure time was $22 \mathrm{~h}$. NHS, normal human serum.

The major portion of IGF I and IGF II elutes in pool I, i.e., together with the large molecular mass native carrier complex (Table I). During IGF I infusion the amount of IGF I associated with this complex increases 4-fold, whereas that of IGF II decreases 15-fold. Altogether, however, the total amount of IGFs I and II in pool I increases only slightly. Apparently, infused IGF I largely displaces endogenous IGF II and, in contrast to GH (see below), does not essentially augment totally available IGF binding sites in the big complex which appears to be saturated with endogenous IGF. Pool II contains seven times more IGF I than before the IGF I infusion. 35\% of the infused IGF I circulates with the newly induced $36-\mathrm{kD}$ binding protein, $61 \%$ with the big complex. IGF II decreases much less (1.8-fold) in pool II than in pool I. Obviously, IGF II is not as easily displaced by IGF I as in the big complex, compatible with a higher affinity of the $36-\mathrm{kD}$ protein for IGF II (24).

Like rhIGF I, GH increases the amount of IGF I associated with pool I fourfold. But, in contrast to IGF I infusion, it does not essentially reduce the amount of IGF II in this pool. Therefore, the total amount of IGFs I and II in pool I is higher than 
Table I. Distribution of Immunoreactive IGF I and II between Serum Pools I, II, and III of a Normal Human Adult before and during rhIGF I or/and rhGH Treatment

\begin{tabular}{|c|c|c|c|c|c|c|}
\hline & \multicolumn{2}{|c|}{$\begin{array}{c}\text { Pool I } \\
(120-300 \mathrm{kD})\end{array}$} & \multicolumn{2}{|c|}{$\begin{array}{c}\text { Pool II } \\
(50-120 \mathrm{kD})\end{array}$} & \multicolumn{2}{|c|}{$\begin{array}{c}\text { Pool III } \\
(21-50 \mathrm{kD})\end{array}$} \\
\hline & IGF I & IGF II & IGF I & IGF II & IGF I & IGF II \\
\hline & \multicolumn{6}{|c|}{$n g$} \\
\hline $\begin{array}{l}\text { Before treatment } \\
\text { rhIGF I ( } 5 \text { d } 30\end{array}$ & 92 & 272 & 29 & 71 & 16 & 20 \\
\hline $\begin{array}{l}\mathrm{mg} / \mathrm{d} \text { s.c. }) \\
\mathrm{rhGH}(4 \mathrm{~d} 2 \times 3\end{array}$ & 389 & 18 & 202 & 39 & 34 & 15 \\
\hline mg/d s.c.) & 405 & 239 & 80 & 55 & 49 & 24 \\
\hline rhGH + rhIGF I & 675 & 61 & 116 & 52 & 57 & 19 \\
\hline
\end{tabular}

$30 \mathrm{mg} / \mathrm{d}$ rhIGF I was infused s.c. for $5 \mathrm{~d} .2 \times 3 \mathrm{mg} / \mathrm{d}$ rhGH was injected s.c. for $4 \mathrm{~d}$. When given in combination, growth hormone was given for $4 \mathrm{~d}$, and then rhIGF I ( $30 \mathrm{mg} / \mathrm{d})$ was administered together with GH for $2 \mathrm{~d}$ more. Pools I, II, and III were obtained by neutral Sephadex G-200 chromatography of 1-ml serum samples as described in Figs. 4 and 5. The three pools correspond to the three molecular mass ranges indicated in Fig. 4. The pools were dialyzed against $0.1 \mathrm{M} \mathrm{NH}_{4} \mathrm{HCO}_{3}$, lyophilized, and redissolved in $1 \mathrm{ml}$ of distilled water. $0.25 \mathrm{ml}$ of each pool was processed on SEP-PAK (see Methods). The radioimmunoassay was carried out as described earlier (22). Results are expressed as nanograms per pool. before treatment or during IGF I infusion. Obviously, GH increases available IGF binding sites. RhIGF I in combination with GH further increases the amount of IGF I in the large complex, but simultaneously reduces IGF II. Thus, the total of IGFs I and II is only slightly higher than with GH alone. Less IGF I is associated with pool II than during IGF I infusion, consistent with the observation that GH suppresses the "induction" of the $36-\mathrm{kD}$ protein by IGF I.

Sera from patients with extrapancreatic tumor hypoglycemia do not only contain more of the $36-\mathrm{kD}$ carrier protein, but show another conspicuous difference from normal serum: a considerable portion of the $42 / 45-\mathrm{kD}$ doublet elutes with the $36-\mathrm{kD}$ band in pool II (Fig. 7) and is, therefore, not associated with the large complex. Consistent with this finding and in contrast to normal serum, $65-70 \%$ of the total IGF is recovered in pools II and III (Table II), whereas in normal serum these pools contain only $21-27 \%$ of the total IGF (Tables I and II).

\section{Discussion}

Assignment of the ligand blot bands to structurally defined IGF carrier proteins

The 42/45 $\mathrm{kD}$ doublet and the $31 \mathrm{kD}$ band. The predominant IGFBP of adult human serum appears as a $42 / 45-\mathrm{kD}$ double band in ${ }^{125} \mathrm{I}-\mathrm{IGF}$ ligand blots under nonreducing conditions, as

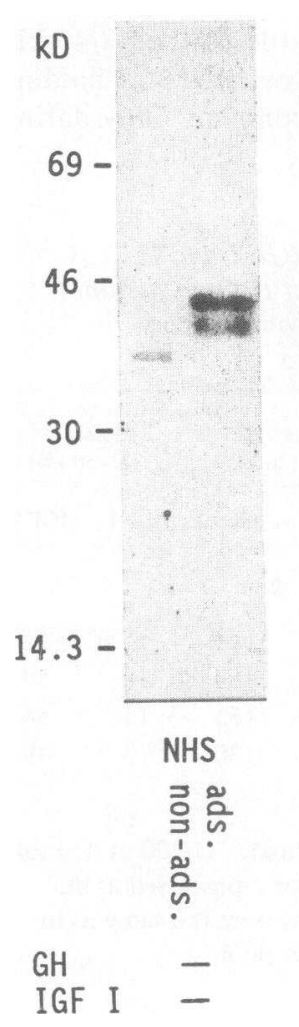

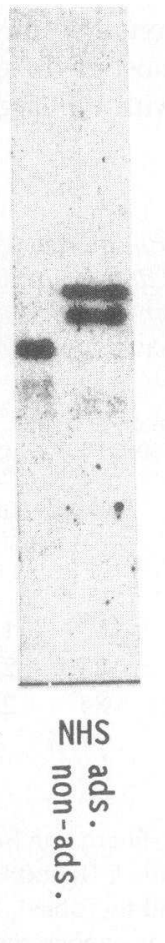

$-$

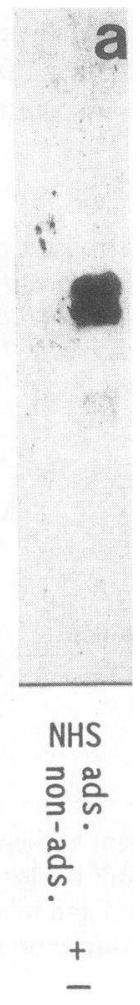

Figure 6. (a) ${ }^{125}$ I-IGF II ligand blot analysis of nonadsorbed and adsorbed fractions obtained by Con A affinity chromatography of sera from a healthy adult (subject 1) before and during treatment with rhIGF I ( 30 $\mathrm{mg} / \mathrm{d}$ infused s.c. for $2 \mathrm{~d}$ ) or hGH $(2 \times 3 \mathrm{mg} / \mathrm{d}$ injected s.c. for $4 \mathrm{~d}$ ). $0.1-\mathrm{ml}$ serum samples were chromatographed on Con A Sepharose columns, dialyzed, and lyophilized as described in Methods. $10-\mu \mathrm{l}$ samples were electrophoresed and processed as described in Methods. Exposure time was $22 \mathrm{~h}$. (b) $\mathrm{N}$-glycanase digestion of the nonadsorbed and adsorbed fractions obtained by Con A Sepharose chromatography of serum from a healthy adult (subject 1) during rhIGF I infusion ( $30 \mathrm{mg} / \mathrm{d}$ for $2 \mathrm{~d}$ ). For details see Methods. Lanes 1 and 2, nonadsorbed fraction; lanes 3 and 4 , adsorbed fraction. 


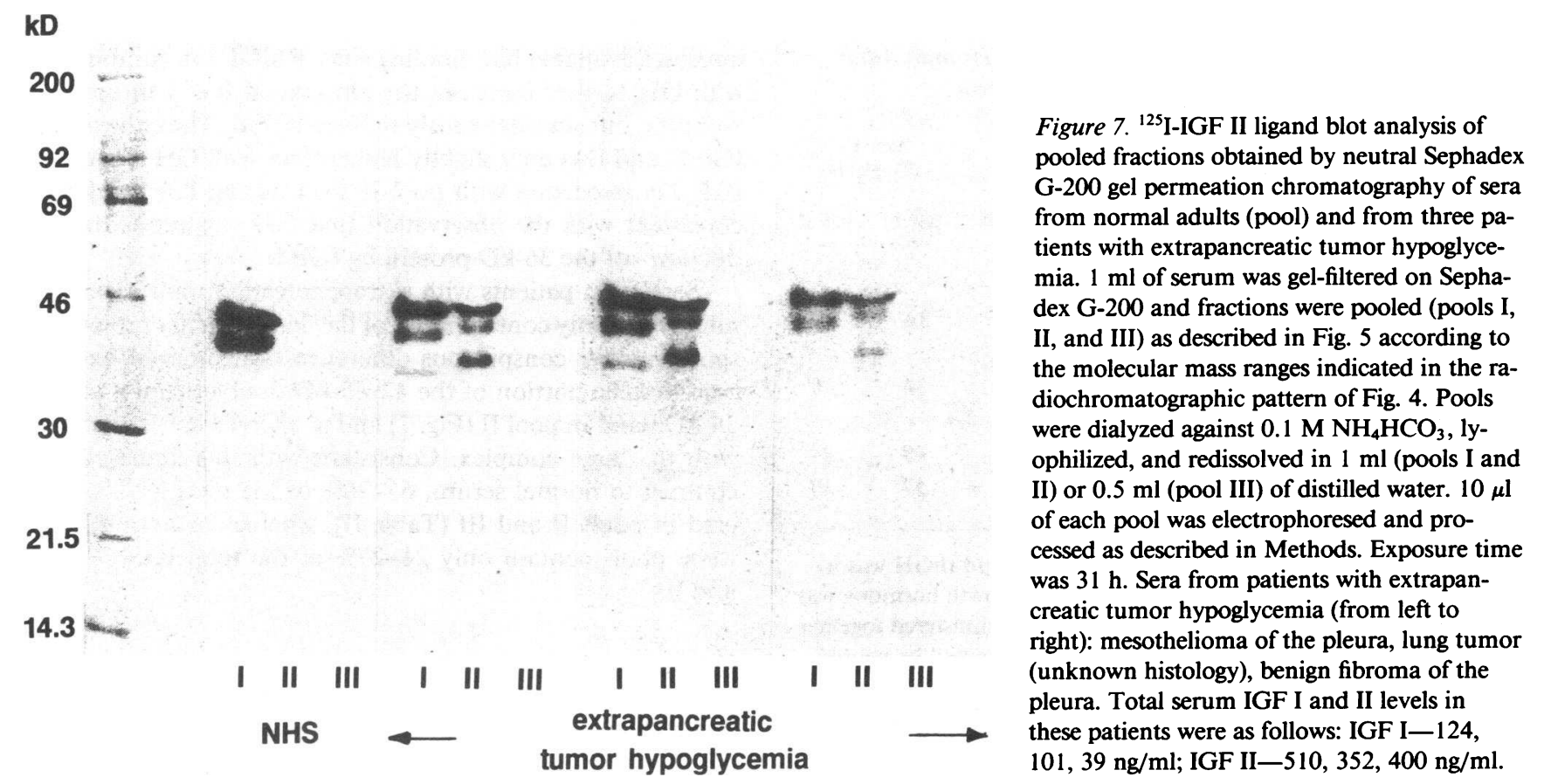

also reported by Hardouin et al. (24). These authors determined apparent molecular masses of 38.5 and $41.5-\mathrm{kD}$ for the two protein bands, whereas Baxter et al. (25) reported apparent molecular masses of 47 and $53-\mathrm{kD}$ for the purified proteins. The $42 / 45-\mathrm{kD}$ proteins are constituents of the $160-180-\mathrm{kD}$ complex of native serum (Figs. 4 and 5). Like Hardouin et al. (24), we do not find any other IGFBP in this complex. The results of Fig. 6 confirm that the complex is glycosylated (26, 27 ) and suggest that its $42 / 45-\mathrm{kD}$ constituents represent two $N$-glycosylation variants of the same protein. This contention is further supported by the finding that the purified $42 / 45-\mathrm{kD}$ doublet yields a unique $\mathrm{NH}_{2}$-terminal sequence (28) as also reported by Baxter et al. (25) for their $47 / 53-\mathrm{kD}$ proteins. This sequence is identical to the $\mathrm{NH}_{2}$ terminus of IGFBP-3 $(20,25$, 29). The $\mathrm{NH}_{2}$ terminus of the purified $31-\mathrm{kD}$ protein, which appears together with the $42 / 45-\mathrm{kD}$ doublet in pool I during IGF I infusion, is the same as that of IGFBP-3 (28). Presumably it is a degradation product of BP-3 lacking the $\mathrm{COOH}$ terminus. A corresponding protein has been isolated from rat serum (11).

The 36-kD band, the major constituent of the small carrier complex. The 36-kD ligand blot band represents a nonglycosylated protein (Fig. 6 b). Hardouin et al. (24) report an apparent molecular mass of 34-kD. It does not cross-react with antiserum to human IGFBP-1 nor to IGFBP-3 (30). On Sephadex G-200 gel permeation chromatography, it elutes between 50 and 120-kD (Figs. 4 and 5). It may, therefore, exist as a dimer in native serum. On ligand blots the purified protein yields an additional weak radioactive signal at 70-kD (J. Zapf, unpublished observation). The $36-\mathrm{kD}$ protein is the predominant IGFBP in human fetal sera (Fig. 1) and in sera from patients with Laron dwarfism (Fig. 1 and reference 30), and it is a major IGFBP in sera from patients with extrapancreatic tumor hypoglycemia (Figs. 1 and 7). We have purified the $36-\mathrm{kD}$ protein and obtained $38 \mathrm{NH}_{2}$-terminal amino acids (28) of the first 24 amino acids, 23 are identical to those of an IGFBP released by BRL $3 A$ rat liver cells (31-33), which has now been termed rat IGFBP-2 (29). We have cloned the cDNA of the human $36-\mathrm{kD}$ protein from a Hep $\mathrm{G} 2$ hepatoma cDNA library and derived the amino acid sequence (28). It is identical (except one amino acid) to a sequence reported by Binkert et al. (34) that is $>85 \%$ homologous to rat IGFBP-2 $(32,33)$.

Beside the $36-\mathrm{kD}$ protein, the $50-120-\mathrm{kD}$ pool (pool II) of normal human serum contains only little of the $42 / 45-\mathrm{kD}$ doublet indicating that most of the glycosylated IGF binding subunits are associated with the large complex. Only during

Table II. Distribution of Immunoreactive IGF I and II between Serum Pools I, II, and III in Adult Human Serum (Normal Serum Pool) and in Three Sera from Patients with Extrapancreatic Tumor Hypoglycemia

\begin{tabular}{|c|c|c|c|c|c|c|}
\hline & \multicolumn{2}{|c|}{$\begin{array}{c}\text { Pool I } \\
(120-300 \text { kD) }\end{array}$} & \multicolumn{2}{|c|}{$\begin{array}{c}\text { Pool II } \\
(50-120 \mathrm{kD})\end{array}$} & \multicolumn{2}{|c|}{$\begin{array}{c}\text { Pool III } \\
(21-50 \mathrm{kD})\end{array}$} \\
\hline & IGF I & IGF II & IGF I & IGF II & IGF I & IGF II \\
\hline & \multicolumn{6}{|c|}{$n g$} \\
\hline Normal serum pool & 88 & 263 & 13 & 44 & 15 & 21 \\
\hline Pattern 1 & 23 & 123 & 29 & 154 & 18 & 59 \\
\hline Pattern 2 & 21 & 84 & 22 & 135 & 11 & 54 \\
\hline Pattern 3 & 8 & 77 & 5 & 130 & 8 & 49 \\
\hline
\end{tabular}

1-ml serum samples were gel-filtered on Sephaxdex G-200 at neutral $\mathrm{pH}$ and fractions pooled (pools I, II, and III) and processed as described in Fig. 5 and in legend to Table I. Sera were the same as in Fig. 7. Results are expressed as nanograms per pool. 
IGF I infusion are significant amounts of the $42 / 45-\mathrm{kD}$ doublet detectable in this pool. Possibly, this reflects a relative lack of the acid-labile subunit. It may be due to suppressed GH secretion during IGF I infusion (21) and would thus confirm findings in the rat (11) suggesting that the synthesis of the acid-labile subunit is not an IGF I-mediated, but a direct effect of GH. Although some "trailing" of the large complex into pool II during gel filtration cannot be excluded, it certainly cannot account for the finding that, in contrast to normal serum, a large portion of $42 / 45-\mathrm{kD}$ IGF binding subunits is found in pool II of sera from patients with extrapancreatic tumor hypoglycemia.

The 33-kD protein representing the second prominent ligand blot band in fetal serum and in serum of Laron dwarfs (Fig. 1) is detected in normal adult serum only during IGF I infusion (Fig. 2, $a$ and $b$ ). It corresponds to the "slow" 30-kD band of Hardouin et al. (30) and cross-reacts with antibodies to amniotic fluid IGFBP (IGFBP-1) (30).

\section{Regulation of the 36- and 42/45-kD binding proteins:} (IGFBP-2 and -3)

The "induction" of the $36-\mathrm{kD}$ BP by IGF I infusion is striking. GH, which raised endogenous IGF I levels to a similar extent as infusion of rhIGF I (Table I), suppresses this protein (Figs. $3, a$ and $b$, and 5). Furthermore, patients with extrapancreatic tumor hypoglycemia have very low IGF I serum levels (35, 36 ), but nevertheless, a greatly enhanced $36-\mathrm{kD}$ ligand blot signal. Therefore, the increase of the $36-\mathrm{kD}$ protein during IGF I infusion is unlikely to be due to a direct IGF I effect. We have recently shown that diabetic rat serum contains a nonglycosylated 33/34-kD IGF binding protein which we did not find in normal adult rat serum $(11,37)$. Most likely it represents rat IGFBP-2. Expression of the mRNA encoding this protein is highly increased in livers of diabetic rats and suppressed by insulin treatment (38). In agreement with these findings, physiological concentrations of insulin inhibit the release from rat hepatocytes in vitro of a $33 / 34-\mathrm{kD}$ nonglycosylated IGFBP (39) and at the same time completely inhibit accumulation of IGFBP-2 mRNA (40). Treatment of hepatocytes with GH or physiological concentrations of IGF I does not affect the release of IGFBP-2 (40). Nor does GH or IGF I treatment of diabetic rats affect the 33/34-kD ligand blot band in the serum of these animals $(11,37)$. However, we consider it very likely that in the human in vivo both insulin and $\mathrm{GH}$ regulate human IGFBP-2 by inhibiting its expression:

1. IGF I infusion suppresses insulin and GH secretion (21), leading to increased expression of IGFBP-2.

2. GH treatment (21) or oversecretion of GH is accompanied by increased insulin secretion (41). When administered together with IGF I, GH suppresses the "induction" of IGFBP- 2 by IGF I.

3. Low insulin levels are found in patients with Laron dwarfism, who are unresponsive to $\mathrm{GH}$ (42), and in patients with extrapancreatic tumor hypoglycemia who have low serum GH levels $(43,44)$. Consequently, IGFBP- 2 is overexpressed in these patients. An increased intensity of a $34-\mathrm{kD}$ band (corresponding to our $36-\mathrm{kD}$ band) has been found in GH-deficient patients $(23,24,30)$ who also have low insulin levels. In contrast, this band is less intense than normal in patients with acromegaly $(24,30)$. Decreased responsiveness to GH may contribute to the increased expression of IGFBP-2 in the fetus.

The GH dependence of the large IGF carrier complex (Fig. $4)$ is well established $(17,18)$. Consequently, the $42 / 45-\mathrm{kD}$ IGF binding subunits (IGFBP-3) (Fig. 3, $a$ and $b$, and references 24 and 30$)$ and the acid-labile subunit $(11,26)$ are also under GH control. GH deficiency $(24,30)$ as well as decreased responsiveness (fetus) or unresponsiveness to GH (Laron dwarf) are accompanied by a reduction or lack of IGFIBP-3 (Fig. 1). BP-3 increased during GH treatment after a lag period of $2 \mathrm{~d}$ (Fig. $3 \mathrm{~b}$ ), i.e., not before the endogenous IGF I had reached levels of $400-500 \mathrm{ng} / \mathrm{ml}$ (21). On the other hand, rhIGF I itself caused an increase of BP-3 and further enhanced the increase of IGFBP-3 due to GH (Figs. $2 b$ and $3 b$ ). In contrast to GH, rhIGF I had already induced BP-3 after 12-24 $\mathrm{h}$, but the induction was transient. BP-3 decreased again under the IGF I infusion (Fig. $2 b$ ) despite elevated serum IGF I levels (21). These results suggest that IGF I induces IGFBP-3 only in the presence of normal or elevated serum $\mathrm{GH}$ and insulin levels (at the beginning of the IGF I infusion or during GH and GH plus IGF I treatment), whereas decreased GH and insulin levels during the IGF I infusion (21) appear to counteract this IGF I effect.

\section{A possible role of IGFBP-2 in glucose homeostasis and in} the development of extrapancreatic tumor hypoglycemia

The increased IGFBP-2 levels during IGF I infusion and the concomitant increase of IGF I circulating with this protein as small carrier complex (pool II, Fig. 4) may affect glucose homeostasis: in contrast to the large IGF carrier complex, the small complex passes the capillary system (4) and thus carries increased amounts of rhIGF I into the interstitial space. The short half-life of IGF associated with the small complex (10, 45 ) indicates a high turnover of this IGF pool. This may further enhance the delivery of rhIGF I into the interstitial space. In addition, the lower affinity of IGFBP-2 for IGF I than for IGF II (24) may facilitate the subsequent release of rhIGF I and its interaction with the type I IGF or the insulin receptor to stimulate glucose uptake in skeletal muscle. Together with the concomitant elevation of free IGF I (21) these mechanisms may explain why during IGF I infusion glucose levels do not rise despite suppressed insulin secretion and decreased serum insulin levels (21). By the same token, increased levels of IGFBP-2 in hypopituitary patients (30), Laron dwarfs (Fig. 1; reference 30 ) and in pygmies (30) might contribute, together with an up-regulation of insulin receptors, to the well-known increased insulin sensitivity in these individuals whose glucose levels are in the normal range despite blunted insulin secretion and low serum insulin levels.

A similar mechanism may contribute to the development of extrapancreatic tumor hypoglycemia as recently also suggested by Daughaday and Kapadia (46). These authors measured IGF II in individual fractions obtained by neutral Sephadex G-200 gel permeation chromatography of sera from three patients with extrapancreatic tumor hypoglycemia. They found most of the IGF II within the molecular mass range of albumin (corresponding to our pools II and III), whereas in normal serum the majority of IGF II elutes with the gamma- 
globulin fraction (corresponding to our pool I). From this abnormal distribution of IGF II they concluded that its tissue accessibility is increased resulting in hypoglycemia. Our findings demonstrate that the $50-120-\mathrm{kD}$ serum pool contains both increased amounts of IGFBP-2 and IGFBP-3 (Fig. 7). The sequestration of IGFBP-3 into pool II indicates a relative lack of the acid-labile subunit which in normal serum occurs in threefold molar excess of IGF and IGFBP-3 (47). The concentration of IGF II circulating with the small carrier complex is two- to threefold higher than in healthy individuals (Table II). Thus, increased amounts of IGF II may reach insulin target cells and elicit insulin-like effects like inhibition of lipolysis and increased glucose consumption. It is unknown whether or not, or in which form, IGF II inhibits or blocks hepatic glucose output. In contrast to other organs where the capillary system restricts the passage of the large IGF carrier complex $(4,48)$, the fenestrated capillary endothelium of the liver does not form a diffusion barrier. The hepatocyte is "bathed" in serum and should, therefore, be also in contact with the large carrier complex. Obviously, the high amounts of IGF II bound to this complex in normal serum are not recognized in this form by the insulin receptor of the hepatocyte. Otherwise, a normal liver would be continuously exposed to a huge insulin-like potential. One could speculate, however, that IGF II reaching the hepatocyte in a different form, namely as the binary IGFIGFBP-3 complex, might be able to block hepatic glucose output in the liver as is typical for extrapancreatic tumor hypoglycemia (49).

Our findings may contribute to smoothing the controversy between several groups of investigators on whether or not IGF II is responsible for extrapancreatic tumor hypoglycemia. Total IGF II levels have been found to be normal $(22,35,36)$ or elevated in this disease $(43,44,49)$. It appears, however, that it is not the total IGF II level which is important in the development of this type of hypoglycemia, but the preferential association of increased amounts of IGF II with the small IGF carrier protein complex in which IGF has a high turnover rate $(45)$.

\section{Acknowledgments}

The devoted and excellent secretarial work of Martha Salman and Irene Buclin is gratefully acknowledged.

This work was supported by grant no. 3.046 .087 from the Swiss National Science Foundation.

\section{References}

1. Daughaday, W. H., and P. Rotwein. 1989. Insulin-like growth factors I and II: peptide, messenger ribonucleic acid and gene structures, serum and tissue concentrations. Endocr. Rev. 10:68-91.

2. Nissley, S. P., and M. M. Rechler. 1984. Insulin-like growth factors: biosynthesis, receptors and carrier proteins. In Hormonal Proteins and Peptides. C. H. Li, editor. Academic Press, Inc. New York. 127-203.

3. Schwander, J., C. Hauri, J. Zapf, and E. R. Froesch. 1983. Synthesis and secretion of insulin-like growth factor and its binding protein by the perfused rat liver: dependence on growth hormone status. Endocrinology. 113:297-305.

4. Binoux, M., and P. Hossenlopp. 1988. Insulin-like growth factor (IGF) and IGF binding proteins: comparison of human serum and lymph. J. Clin. Endocrinol. Metab. 67:509-514.

5. Hossenlopp, P., D. Seurin, B. Segovia-Quinson, and M. Binoux. 1986. Identification of an insulin-like growth factor binding protein in human cerebral spinal fluid with a selective affinity for IGF II. FEBS (Fed. Eur. Biochem. Soc.) Lett. 208:439-444.

6. Hossenlopp, P., D. Seurin, B. Segovia, G. Portolan, and M. Binoux. 1987. Heterogeneity of insulin-like growth factor binding proteins and relationships between structure and affinity. II. Forms released by human and rat liver in culture. Eur. J. Biochem. 170:133142.

7. Schmid, C., J. Zapf, and E. R. Froesch. 1989. Production of carrier proteins for insulin-like growth factors (IGFs) by rat osteoblastic cells. Regulation by IGF I and cortisol. FEBS (Fed. Eur. Biochem. Soc.) Lett. 244:328-332.

8. Schmid, C., M. Ernst, J. Zapf, and E. R. Froesch. 1989. Release of insulin-like growth factor carrier proteins by osteoblasts: stimulation by estradiol and growth hormone. Biochem. Biophys. Res. Commun. 160:788-794.

9. Cohen, K. L., and S. P. Nissley. 1976. The serum half-life of somatomedin activity: evidence for growth hormone dependence. Acta Endocrinol. 83:243-258.

10. Zapf, J., C. Hauri, M. Waldvogel, and E. R. Froesch. 1986. Acute metabolic effects and half-lives of intravenously administered insulin-like growth factors I and II in normal and hypophysectomized rats. J. Clin. Invest. 77:1768-1775.

11. Zapf, J., C. Hauri, M. Waldvogel, E. Futo, H. Häsler, K. Binz, H. P. Guler, C. Schmid, and E. R. Froesch. 1989. Recombinant human insulin-like growth factor I induces its own specific carrier protein in hypophysectomized and diabetic rats. Proc. Natl. Acad. Sci. USA. 86:3813-3817.

12. Elgin, R. G., W. H. Busby, and D. R. Clemmons. 1987. An insulin-like growth factor (IGF) binding protein enhances the biologic response to IGF I. Proc. Natl. Acad. Sci. USA 84:3254-3258.

13. De Mellow, J. S. M., and R. C. Baxter. 1988. Growth hormone-dependent insulin-like growth factor (IGF) binding protein both inhibits and potentiates IGF I-stimulated DNA synthesis in human skin fibroblasts. Biochem. Biophys. Res. Commun. 156:199-204.

14. Knauer, D. J., and G. L. Smith. 1980. Inhibition of biologic activity of multiplication-stimulating activity by binding to its carrier protein. Proc. Nat. Acad. Sci. USA. 77:7252-7256.

15. Guler, H.-P., J. Zapf, E. Scheiwiller, and E. R. Froesch. 1988. Recombinant human insulin-like growth factor I stimulates growth and has distinct effects on organ size in hypophysectomized rats. Proc. Natl. Acad. Sci. USA. 85:4889-4893.

16. Zapf, J., M. Waldvogel, and E. R. Froesch. 1975. Binding of nonsuppressible insulinlike activity to human serum. Evidence for a carrier protein. Arch. Biochem. Biophys. 168:638-645.

17. Hintz, R. L., F. Liu, R. G. Rosenfeld, and S. F. Kemp. 1981. Plasma somatomedin binding proteins in hypopituitarism: changes during growth hormone therapy. J. Clin. Endocrinol. Metab. 53:100104.

18. Martin, J. L., and R. C. Baxter. 1981. Antibody against acidstable insulin-like growth factor binding protein detects $150,000 \mathrm{~mol}$ wt growth hormone-dependent complex in human plasma. J. Clin. Endocrinol. Metab. 61:799-801.

19. Baxter, R. C., and J. L. Martin. 1989. Structure of the $M_{\mathrm{r}}$ $140^{\prime} 000$ growth hormone-dependent insulin-like growth factor binding protein complex: determination by reconstitution and affinity-labeling. Proc. Natl. Acad. Sci. USA. 86:6898-6902.

20. Wood, W. I., G. Cachianes, W. J. Henzel, G. A. Winslow, S. A. Spencer, R. Hellmiss, J. L. Martin, and R. C. Baxter. 1988. Cloning and expression of the growth hormone-dependent insulin-like growth factor binding protein. Mol. Endocrinol. 2:1176-1185.

21. Guler, H. P., C. Schmid, J. Zapf, and E. R. Froesch. 1989. Effects of recombinant insulin-like growth factor $I$ on insulin secretion and renal function in normal human subjects. Proc. Natl. Acad. Sci. USA. 86:2868-2872.

22. Zapf, J., H. Walter, and E. R. Froesch. 1981. Radioimmunological determination of insulinlike growth factors I and II in normal subjects and in patients with growth disorders and extrapancreatic tumor hypoglycemia. J. Clin. Invest. 68:1321-1330. 
23. Hossenlopp, P., D. Seurin, B. Segovia-Quinson, S. Hardouin, and M. Binoux. 1986. Analysis of serum insulin-like growth factor binding proteins using Western blotting: use of the method for titration of the binding proteins and competitive binding studies. Anal. Biochem. 154:138-143.

24. Hardouin, S., P. Hossenlopp, B. Segovia, D. Seurin, G. Portolan, C. Lassarre, and M. Binoux. 1987. Heterogeneity of insulin-like growth factor binding proteins and relations between structure and affinity. I. Circulating forms in man. Eur. J. Biochem. 170:121-132.

25. Baxter, R. C., J. L. Martin, M. I. Tyler, and M. E. H. Howden. Growth hormone-dependent insulin-like growth factor (IGF) binding protein from human plasma differs from other human IGF binding proteins. Biochem. Biophys. Res. Commun. 139:1256-1261.

26. Furlanetto, R. W. 1980. The somatomedin C binding protein: evidence for a heterologous subunit structure. J. Clin. Endocrinol. Metab. 51:12-19.

27. Wilkins, J. R., and A. J. D'Ercole. 1985. Affinity-labeled plasma somatomedin $\mathrm{C} /$ insulin-like growth factor I binding proteins: evidence of growth hormone-dependence and subunit structure. $J$. Clin. Invest. 75:1350-1358.

28. Zapf, J., M. Kiefer, J. Merryweather, F. Masiarz, D. Bauer, W. Born, J. A. Fischer, and E. R. Froesch. 1990. Isolation from adult human serum of four insulin-like growth factor binding proteins and molecules cloning of one of them that is increased by IGF I administration and in extracellular tumor hypoglycemia. J. Biol. Chem. In press.

29. Ballard, J., R. C. Baxter, M. Binoux, D. Clemmons, S. Drop, K. Hall, R. L. Hintz, M. M. Rechler, E. Rutanen, and J. J. Schwander. 1989. On the nomenclature of the IGF binding proteins. Acta Endocrinol. 121:751-752.

30. Hardouin, S., M. Gourmelen, P. Noguiez, D. Seurin, M. Roghani, Y. Le Bouc, G. Povoa, T. J. Merimee, P. Hossenlopp, and M. Binoux. 1989. Molecular forms of serum insulin-like growth factor (IGF) binding proteins in man: relationships with growth hormone and IGFs and physiological significance. J. Clin. Endocrinol. Metab. 69:1291-1301.

31. Mottola, C., R. G. MacDonald, J. L. Brackett, J. E. Mole, J. K. Anderson, and M. P. Czech. 1986. Purification and amino-terminal sequence of an insulin-like growth factor binding protein secreted by rat liver BRL-3A cells. J. Biol. Chem. 261:11180-11188.

32. Margot, J. B., C. Binkert, J.-L. Mary, J. Landwehr, G. Heinrich, and J. Schwander. 1989. A low molecular weight insulin-like growth factor binding protein from rat: cDNA cloning and tissue distribution of its messenger RNA. Mol. Endocrinol. 3:1053-1060.

33. Brown, A. L., L. Chiariotti, C. C. Orlowski, T. Mehlman, W. H. Burgess, E. J. Ackerman, C. B. Bruni, and M. M. Rechler. 1989. Nucleotide sequence and expression of a cDNA clone encoding a fetal rat binding protein for insulin-like growth factors. J. Biol. Chem. 264:5148-5154.

34. Binkert, C., J. Landwehr, J.-L. Mary, J. Schwander, and G. Heinrich. 1989. Cloning, sequence analysis and expression of a cDNA encoding a novel insulin-like growth factor binding protein (IGFBP-2). EMBO (Eur. Mol. Biol. Organ.) J. 8:2497-2502.

35. Zapf, J., B. Morell, H. Walter, Z. Laron, and E. R. Froesch. 1980. Serum levels of insulin-like growth factor (IGF) and its carrier protein in various metabolic disorders. Acta Endocrinol. 95:505-517.

36. Widmer, U., J. Zapf, and E. R. Froesch. 1982. Is extrapancreatic tumor hypoglycemia associated with elevated levels of insulin-like growth factor II? J. Clin. Endocrinol. Metab. 55:833-839.

37. Zapf, J., C. Schmid, H. P. Guler, K. Binz, and E. R. Froesch. 1989. Effects of growth hormone insulin and IGF I treatment on IGF carrier proteins in hypophysectomized and diabetic rats: comparison with fasting and refeeding. In Insulin-like Growth Factor Binding Proteins. S. L. S. Drop and R. L. Hintz, editors. Excerpta Medica, Amsterdam. 151-156.

38. Böni-Schnetzler, M., K. Binz, J.-L. Mary, C. Schmid, J. Schwander, and E. R. Froesch. 1989. Regulation of hepatic expression of IGF I and fetal IGF binding protein mRNA in streptozotocin-diabetic rats. FEBS (Fed. Eur. Biochem. Soc.) Lett. 251:253-256.

39. Schmid, C., J. Zapf, P. Meier, M. Böni-Schnetzler, M. Ernst, and E. R. Froesch. 1989. Hormonal regulation of insulin-like growth factor binding proteins from cultured rat hepatocytes and osteoblasts. In Insulin-like Growth Factor Binding Proteins. S. L. S. Drop and R. L. Hintz, editors. Excerpta Medica, Amsterdam. 267-272.

40. Böni-Schnetzler, M., C. Schmid, J.-L. Mary, B. Zimmerli, P. J. Meier, J. Zapf, J. Schwander, and E. R. Froesch. 1990. Insulin regulates the expression of the insulin-like growth factor binding protein (IGFBP)-2 mRNA in rat hepatocytes. Mol. Endocrinol. In press.

41. Fineberg, S. E., T. J. Merimee, D. Rabinowitz, and P. J. Edgar. 1970. Insulin secretion in acromegaly. J. Clin. Endocrinol. Metab. 30:288-292.

42. Laron, Z. 1974. Syndrome of familial dwarfism and high plasma immunoreactive growth hormone. Isr. J. Med. Sci. 10:12471253.

43. Daughaday, W. H., M. A. Emanuelle, M. H. Brooks, A. L. Barbato, M. Kapadia, and P. Rotwein. 1988. Synthesis and secretion of insulin-like growth factor II by a leiomyosarcoma with associated hypoglycemia. N. Engl. J. Med. 319:434-440.

44. Ron, D., A. C. Powers, M. R. Pandian, J. E. Godine, and L. Axelrod. 1989. Increased insulin-like growth factor II production and consequent suppression of growth hormone secretion: a dual mechanism for tumor-induced hypoglycemia. J. Clin. Endocrinol. Metab. 68:701-706.

45. Guler, H. P., J. Zapf, C. Schmid, and E. R. Froesch. 1989. Insulin-like growth factors I and II in healthy man: estimation of half-lives and production rates. Acta Endocrinol. 121:753-758.

46. Daughaday, W. H., and M. Kapadia. 1989. Significance of abnormal serum binding of insulin-like growth factor II in the development of hypoglycemia in patients with non-islet-cell tumors. Proc. Natl. Acad. Sci. USA. 86:6778-6782.

47. Baxter, R. C., J. L. Martin, and V. A. Beniac. 1989. High molecular weight insulin-like growth factor binding protein complex: Purification and properties of the acid-labile subunit from human serum. J. Biol. Chem. 264:11843-11848.

48. Meuli, C., J. Zapf, and E. R. Froesch. 1978. NSILA-carrier protein abolishes the action of nonsuppressible insulin-like activity (NSILA-S) on perfused rat heart. Diabetologia. 14:255-259.

49. Kahn, C. R. 1980. The riddle of tumor hypoglycemia. Clin. Endocrinol. Metab. 9:335-360. 